\title{
An Examination of Self-Perception Mediation of the Foot-in-the-Door Effect
}

\author{
William DeJong \\ Brandeis University
}

\begin{abstract}
In 1966, Freedman and Fraser demonstrated that an individual is more likely to comply with a large request for help if that person has previously agreed to an initial small request-a phenomenon they called the "foot-in-the-door" effect. In the present survey, studies that have sought to replicate the foot-inthe-door effect are reviewed. The adequacy of a self-perception explanation for the foot-in-the-door effect is assessed by examining (a) the importance of the size of the initial request; (b) the effect of noncompliance with the initial request; (c) the impact of salient external justifications for the initial act of compliance; (d) the impact of social labels on subsequent levels of compliance; and (e) attempts at actually measuring changes in self-perception. Alternative explanations of the foot-in-the-door effect are considered and rejected, and directions for future research are outlined.
\end{abstract}

In 1966 Freedman and Fraser tested the notion that once an individual has complied with a small, sometimes trivial request, that person will be more likely to comply with a larger and more substantial demand made in the future-an effect they christened the "foot-in-the-door" phenomenon. During the last 12 years, social psychologists have continued to be fascinated by those results. How is it that the simple act of assenting to a small request for help can dramatically increase, even double, the probability of a person's agreeing to give help in the future?

Because the foot-in-the-door paradigm has become an important vehicle by which to study the link between self-concept and behavior, it is important to take a step back and ask some basic questions about the progress of this research: (a) Is the foot-in-the-door

Preparation of this article was supported in part by Public Health Service Postdoctoral Fellowship 1/F32/MH07294-01.

My deepest appreciation is extended to Teresa Amabile, Nancy Cantor, David Funder, Albert Hastorf, Mark Lepper, and David Rosenhan for their comments on an earlier draft of this article.

Requests for reprints should be sent to William DeJong, Department of Psychology, Brandeis University, Waltham, Massachusetts 02154 . effect a reliable one? Under how wide a range of situations has it been demonstrated? (b) Self-perception theory (Bem, 1972) is most often used to explain the effect. What hypotheses can be derived from this explanation, and what evidence has been gathered for each of them? (c) How else can the phenomenon be explained? What is the evidence for and against the alternative propositions that have been offered? (d) What directions can future research take? It was in the hope of answering these questions that the present article was designed. First, I begin with a review of the Freedman and Fraser (1966) experiment.

\section{The Freedman and Fraser Study}

The procedure of their experiment was straightforward. A male experimenter first contacted several suburban housewives in their homes, identifying himself as a member of either the Community Committee for Traffic Safety or the Keep California Beautiful Committee. The initial requests he made of these women were small and innocuous, and almost all of the subjects agreed to them. Half were asked to display a small sign in the front window of their homes. The other sub- 
jects were asked to sign a petition advocating certain legislation. These requests were concerned with one of two issues, driving safety or making California more beautiful.

Two weeks later, the housewives were again contacted. A different experimenter, who claimed to be a representative from the Citizens for Safe Driving, asked the women if they would be willing to have a large, ugly billboard reading "Drive Carefully" installed in their front yard for a period of one week. Thus emerged a simple two-way factorial design. For half of the subjects this second request was like the first in terms of the action required of them (i.e., displaying a sign). For those who had previously signed a petition, the action now required of them was quite different. As a cross-dimension, the issue of concern was the same as before for half of the subjects (i.e., driving safety). Those originally approached by the Keep California Beautiful Committee were now dealing with a different issue.

Freedman and Fraser demonstrated a footin-the-door effect of remarkable strength and generality. Each of the four experimental conditions produced significantly greater compliance with the final request than did a control condition in which subjects were not approached with a first request: Only 20\% of the subjects in that control condition were willing to have the billboard installed, compared with $55 \%$ of the experimental subjects. To be sure, those subjects for whom the second request was similar to the first along the two dimensions of issue of concern and mode of action were somewhat more helpful than subjects in the other three experimental conditions, but that difference did not approach statistical significance. This increased compliance effect did not seem to depend much on the type of request that had been made initially. Even the seemingly trivial action of agreeing to sign a petition about the need to "keep California beautiful" more than doubled the probability that a subject would agree to display a billboard that exhorted motorists to drive more safely. The exciting feature of these results is that the effect cannot be explained merely in terms of either the subject's involvement with a particular experimenter or her increased commitment to a certain issue or mode of action. As Freedman and Fraser recognized, a more complicated (and psychologically interesting) explanation is required.

\section{Attempts at Replication}

Since Freedman and Fraser's (1966) original report, several replications of the foot-inthe-door effect have been attempted. Before this research is reviewed, the criteria that any study must meet before it can be considered a valid replication attempt should be listed:

1. Obviously, a proper control group, consisting of subjects not receiving an initial request, must be included as part of the experimental design. Three studies must be excluded for this reason: Harris, Liguori, and Joniak (1973); Harris and Samerotte (1975); and Schmidt (1973). The first two, in all fairness, were not explicitly designed to test for a footin-the-door effect.

2. The data analysis must include all subjects assigned to the experimental condition and not just those who agree to the first request. Any analysis that excludes those not complying with the first request can be criticized on grounds of differential subject selfselection. Studies by Arbuthnot et al. (19761977) and Beaman, Svanum, Manlove, and Hampton (1974) must be excluded from consideration because of this problem.

3. High compliance with the initial request must be obtained. Harris, Liguori, and Stack (1973, Study 3), for example, failed to obtain a significant foot-in-the-door effect, but interpretation of their findings is made problematic by the fact that only $42 \%$ of their experimental subjects agreed to the first request (see also, Dutton \& Lennox, 1974). Ideally, of course, $100 \%$ of the subjects would consent to the first request, but that goal is rarely obtained. Some studies have reported a significant foot-in-the-door effect with a rate of initial compliance as low as $67 \%$ (e.g., Freedman \& Fraser, 1966, Study 1).

It should be noted that in testing for significant foot-in-the-door effects, each experimental group should be compared individually with the control group. Some studies (e.g., 
Cann, Sherman, \& Elkes, 1975; Harris, 1972, Study 1) combined experimental groups in their analyses, and the data from such studies have been reanalyzed when possible.

Table 1 summarizes known replications of the foot-in-the-door phenomenon that had been attempted by the time of this review (November 1978). The table lists the two requests made of the subjects, the rate of compliance with the second request for both the experimental groups and the no-initialrequest control group, and the conclusions drawn from appropriate statistical comparisons.

A glance at the table shows that a significant foot-in-the-door effect was not always found. It is unwarranted, however, to declare that the effect cannot be reliably obtained. It must be noted that only a few studies (Cann, 1976; Cialdini \& Ascani, 1976; Cialdini, Cacioppo, Basset, \& Miller, 1978; DeJong \& Funder, 1977, Study 1; Harris \& Samerotte, 1976; Miller \& Suls, 1977; Tipton \& Browning, 1972; DeJong, Note 2) showed the percentage of compliance with the second request for one or more experimental groups to be lower than or equal to that for the control group. Thus, almost all of the failures to replicate were in the predicted direction, but did not reach traditional levels of statistical significance. And as noted previously, two failures to replicate (Dutton \& Lennox, 1974; Harris, Liguori, \& Stack, 1973, Study 3) are difficult to interpret because of the very low levels of compliance with the first request in the experimental group.

The subsequent discussion of many of these studies reveals other potential explanations for failures to replicate. They can be mentioned here briefly. First, the initial request must be large enough to cause people to think about the implications of their own behavior; if the request is too small, the effect will probably not be obtained (Seligman, Bush, \& Kirsch, 1976). Thus, for example, it may be that a request to take a small card is too small to increase compliance with a high-cost request like donating blood (Cialdini \& Ascani, 1976). Moreover, some evidence suggests that if the initial request is too large, the probability of obtaining the effect will be reduced (Baron, 1973; Miller \& Suls, 1977). Second, people must feel that their initial compliance resulted from the exercise of free choice, not because of pressure to comply (Uranowitz, 1975; Zuckerman, Lazzaro, \& Waldgeir, in press). Fish and Kaplan's (1974) findings are difficult to interpret for this reason. Subjects in their experiment were first asked to write an essay on various ways of fighting poverty, but they were asked to do this as part of a class about the poverty program. It is possible, then, that the subjects may have felt pressured into writing the essay because they saw it as a class assignment.

A key issue of concern is the generality of the foot-in-the-door phenomenon. Under how wide a range of situations has it been demonstrated? As Table 1 reveals, most of the requests that have been made of subjects involved little time or effort. But some did involve major commitments on the part of the subjects. For example, Lowman (1973) used the foot-in-the-door technique to increase household participation in a complicated trash recycling program. In one study, Freedman and Fraser (1966, Study 1) induced housewives to allow a survey team of five or six men to come into their homes to classify the household products they used.

The length of the delay between the two requests has also been varied. The foot-in-thedoor effect has been demonstrated with delays between the two requests of up to two weeks (e.g., Freedman \& Fraser, 1966, Study 2; Harris, 1972, Study 2), but most successful replications have involved much smaller delays of a day or two. The effect of delay has never been systematically explored, save Cann et al.'s (1975, Study 1) comparison between delay (7-10 days) and no-delay procedures (see Table 1). The length of the delay itself may be less important than whether the occasion of the second request somehow reminds people of their earlier behavior.

The degree of similarity between the two requests is an important dimension as well. Unfortunately, most investigators have employed requests that share many common features, so that the robustness of the foot-inthe-door phenomenon has rarely been put to 
Table 1

Replications of the Foot-in-the-Door Effect

\begin{tabular}{|c|c|c|c|c|}
\hline Study & First request & Second request & Results $^{\mathrm{a}}$ & $\begin{array}{l}\text { Con- } \\
\text { clusion }\end{array}$ \\
\hline $\begin{array}{l}\text { Baer, Goldman, \& } \\
\text { Juhnke (1977) }\end{array}$ & $\begin{array}{l}\text { (1) Give the time to } \\
\text { experimenter } \\
\text { (2) Same as (1); later } \\
\text { misinformation given to } \\
\text { different experimenter }\end{array}$ & $\begin{array}{l}\text { Correct misinformation given to } \\
\text { experimenter by another } \\
\text { elevator passenger }\end{array}$ & $\begin{array}{l}\text { (1) } 70 \\
\text { (2) } 35 \\
\text { (C) } 33\end{array}$ & $\begin{array}{l}\text { FITD } \\
\text { No FITD }\end{array}$ \\
\hline Baron (1973) & $\begin{array}{l}\text { (1) Accept leaflet on the } \\
\text { dangers of pollution } \\
\text { (2) Sign antipollution peti- } \\
\text { tion, get two friends to } \\
\text { sign, and mail in }\end{array}$ & $\begin{array}{l}\text { Agree to put } 3 \text { foot } \times 5 \text { foot } \\
\text { antipollution sign in front } \\
\text { yard }\end{array}$ & $\begin{array}{l}\text { (1) } 50^{b} \\
\text { (2) ? } \\
\text { (C) } 20\end{array}$ & $\begin{array}{l}\text { FITD } \\
\text { No FITD }\end{array}$ \\
\hline Cann (1976) & $\begin{array}{l}\text { (1) Agree to receive a } \\
\text { questionnaire on recycl- } \\
\text { ing in the mail and fill it } \\
\text { out }\end{array}$ & $\begin{array}{l}\text { Volunteer time for a neighbor- } \\
\text { hood cleanup project }\end{array}$ & $\begin{array}{l}\text { (1) } 26 \\
\text { (C) } 26\end{array}$ & No FITD \\
\hline $\begin{array}{l}\text { Cann, Sherman, } \\
\text { \& Elkes (1975, } \\
\text { Study 1) }\end{array}$ & $\begin{array}{l}\text { (1) Answer three questions } \\
\text { on driving habits; no } \\
\text { delay between the two } \\
\text { requests } \\
\text { (2) Same as (1); } 7 \text {-10-day } \\
\text { delay between requests }\end{array}$ & $\begin{array}{l}\text { Agree to accept } 15 \text { pamphlets } \\
\text { on traffic safety and dis- } \\
\text { tribute to neighbors }\end{array}$ & $\begin{array}{l}\text { (1) } 78 \\
\text { (2) } 70 \\
\text { (C) } 50\end{array}$ & $\begin{array}{l}\text { FITD } \\
\text { No FITD }\end{array}$ \\
\hline $\begin{array}{l}\text { Cann, Sherman, } \\
\text { \& Elkes (1975, } \\
\text { Study 2) }\end{array}$ & $\begin{array}{l}\text { (1) Answer three questions } \\
\text { on driving habits; no } \\
\text { delay between the two } \\
\text { requests }\end{array}$ & $\begin{array}{l}\text { Agree to accept } 15 \text { pamphlets } \\
\text { on traffic safety and distri- } \\
\text { bute to neighbors }\end{array}$ & $\begin{array}{l}\text { (1) } 72 \\
\text { (C) } 45\end{array}$ & No FITD \\
\hline $\begin{array}{l}\text { Cialdini \& Ascani } \\
\quad(1976)\end{array}$ & $\begin{array}{l}\text { (1) Take and display small } \\
\text { card advertising blood } \\
\text { drive }\end{array}$ & $\begin{array}{l}\text { Agree to donate blood the next } \\
\text { day }\end{array}$ & $\begin{array}{l}\text { (1) } 32 \\
\text { (C) } 32\end{array}$ & No FITD \\
\hline $\begin{array}{l}\text { Cialdini, Cacioppo, } \\
\text { Basset, \& Miller } \\
\text { (1978, Study 2) }\end{array}$ & $\begin{array}{l}\text { (1) Agree to display a } \\
\text { United Way window } \\
\text { poster }\end{array}$ & $\begin{array}{l}\text { Agree to pick up a United Way } \\
\text { poster packet at dormitory } \\
\text { lobby }\end{array}$ & $\begin{array}{l}\text { (1) } 70^{\circ} \\
\text { (C) } 70\end{array}$ & No FITD \\
\hline $\begin{array}{l}\text { Crano \& Sivacek } \\
\text { (Note 1, Study } \\
\text { 1) }\end{array}$ & $\begin{array}{l}\text { (1) Answer } 10 \text { questions } \\
\text { about beverages }\end{array}$ & $\begin{array}{l}\text { Agree to answer } 30 \text { questions } \\
\text { on driving habits }\end{array}$ & $\begin{array}{l}\text { (1) } 66 \\
\text { (C) } 31\end{array}$ & FITD \\
\hline $\begin{array}{l}\text { Crano \& Sivacek } \\
\text { (Note } 1 \text {, Study } \\
\text { 2) }\end{array}$ & $\begin{array}{l}\text { (1) Answer } 10 \text { questions on } \\
\text { household products }\end{array}$ & $\begin{array}{l}\text { Agree to answer } 45 \text { questions } \\
\text { on the mass media }\end{array}$ & $\begin{array}{l}\text { (1) } 56 \\
\text { (C) } 32\end{array}$ & No FITD \\
\hline DeJong (Note 2) & $\begin{array}{l}\text { (1) Agree to sign a petition } \\
\text { for pro-disabled legisla- } \\
\text { tion; learn they were one } \\
\text { of many to sign } \\
\text { (2) Same as (1); learn they } \\
\text { were the first to sign }\end{array}$ & $\begin{array}{l}\text { Notify a second experimenter } \\
\text { that he dropped a quarter }\end{array}$ & $\begin{array}{l}\text { (1) } 64 \\
\text { (2) } 28 \\
\text { (C) } 32\end{array}$ & $\begin{array}{l}\text { FITD } \\
\text { No FITD }\end{array}$ \\
\hline $\begin{array}{l}\text { De Jong \& Funder } \\
\quad(1977, \text { Study 1) }\end{array}$ & $\begin{array}{l}\text { (1) Answer } 15 \text { questions on } \\
\text { the quality of life in the } \\
\text { local community }\end{array}$ & $\begin{array}{l}\text { Agree to answer } 50 \text { questions } \\
\text { on highway safety }\end{array}$ & $\begin{array}{l}\text { (1) } 46 \\
\text { (C) } 56\end{array}$ & No FI'TD \\
\hline
\end{tabular}


Table 1 (continued)

\begin{tabular}{|c|c|c|c|c|}
\hline Study & First request & Second request & Results $^{\wedge}$ & $\begin{array}{l}\text { Con- } \\
\text { clusion }\end{array}$ \\
\hline $\begin{array}{r}\text { DeJong \& Funder } \\
(1977, \text { Study 2) }\end{array}$ & $\begin{array}{l}\text { (1) Answer } 15 \text { questions on } \\
\text { quality of life in the } \\
\text { local community; receive } \\
\text { letter acknowledging } \\
\text { participation }\end{array}$ & $\begin{array}{l}\text { Agree to answer } 50 \text { questions } \\
\text { on highway safety }\end{array}$ & $\begin{array}{l}\text { (1) } 66 \\
\text { (C) } 56\end{array}$ & No FITD \\
\hline $\begin{array}{l}\text { DeJong \& Musilli } \\
\quad \text { (Note 3) }\end{array}$ & $\begin{array}{l}\text { (1) Agree to participate in } \\
\text { a 5-minute survey on } \\
\text { parking facilities for } \\
\text { compact cars; experi- } \\
\text { menter appeared } \\
\text { physically normal } \\
\text { (2) Agree to participate in } \\
\text { a } 5 \text {-minute survey on } \\
\text { parking facilities for dis- } \\
\text { abled drivers; experi- } \\
\text { menter appeared phys- } \\
\text { ically normal }\end{array}$ & $\begin{array}{l}\text { Agree to participate in a } 30- \\
\text { minute telephone survey on } \\
\text { highway laws and driving } \\
\text { hazards }\end{array}$ & $\begin{array}{l}\text { (1) } 55 \\
\text { (2) } 53 \\
\text { (C) } 40\end{array}$ & $\begin{array}{l}\text { FITD } \\
\text { No FITD }\end{array}$ \\
\hline $\begin{array}{l}\text { Dutton \& Lennox } \\
\quad(1974)\end{array}$ & $\begin{array}{l}\text { (1) Give money to a white } \\
\text { panhandler }\end{array}$ & $\begin{array}{l}\text { Agree to donate time to various } \\
\text { activities as part of an inter- } \\
\text { racial Brotherhood Week }\end{array}$ & $\begin{array}{l}\text { (1) } 54.8^{d} \\
\text { (C) } 46.2\end{array}$ & No FITD \\
\hline $\begin{array}{l}\text { Fish \& Kaplan } \\
\quad(1974)\end{array}$ & $\begin{array}{l}\text { (1) Write a short essay on } \\
\text { ways of fighting poverty }\end{array}$ & $\begin{array}{l}\text { Volunteer time and services to } \\
\text { a welfare agency }\end{array}$ & $\begin{array}{l}\text { (1) } 36 \\
\text { (C) } 33\end{array}$ & No FITD \\
\hline $\begin{array}{l}\text { Freedman \& Fraser } \\
(1966, \text { Study 1) }\end{array}$ & $\begin{array}{l}\text { (1) Answer eight questions } \\
\text { on household soaps } \\
\text { (2) Agree to be in survey } \\
\text { on households soaps }\end{array}$ & $\begin{array}{l}\text { Agree to allow six-man survey } \\
\text { team to enter home and } \\
\text { spend } 2 \text { hours classifying all } \\
\text { household products }\end{array}$ & $\begin{array}{l}\text { (1) } 53 \\
\text { (2) } 33 \\
\text { (C) } 22\end{array}$ & $\begin{array}{l}\text { FITD } \\
\text { No FITD }\end{array}$ \\
\hline $\begin{array}{l}\text { Harris }(1972 \\
\text { Study } 1)\end{array}$ & $\begin{array}{l}\text { (1) Give directions } \\
\text { (2) Give the time }\end{array}$ & Give the experimenter a dime & $\begin{array}{l}\text { (1) } 39 \\
\text { (2) } 44 \\
\text { (C) } 11\end{array}$ & $\begin{array}{l}\text { No FITD } \\
\text { FITD }\end{array}$ \\
\hline $\begin{array}{l}\text { Harris }(1972, \\
\text { Study 2) }\end{array}$ & $\begin{array}{l}\text { (1) Write a letter to a } \\
\text { minority high school stu- } \\
\text { dent, indicating willing- } \\
\text { ness to answer questions } \\
\text { about the university and } \\
\text { student life }\end{array}$ & $\begin{array}{l}\text { Sign class list to volunteer } \\
\text { time to a university publicity } \\
\text { campaign }\end{array}$ & $\begin{array}{lr}\text { (1) } & 18 \\
\text { (C) } 9\end{array}$ & FITD \\
\hline $\begin{array}{l}\text { Harris, Liguori, \& } \\
\text { Stack (1973, } \\
\text { Study 3) }\end{array}$ & $\begin{array}{l}\text { (1) Allow name to be sent } \\
\text { to local congressman as } \\
\text { supporter of organiza- } \\
\text { tion's programs }\end{array}$ & $\begin{array}{l}\text { Agree to donate money or } \\
\text { cookies to a fund-raising } \\
\text { baked-cookie sale }\end{array}$ & $\begin{array}{l}\text { (1) } 30 \\
\text { (C) } 25\end{array}$ & No FITD \\
\hline $\begin{array}{l}\text { Harris \& Samerotte } \\
\quad(1976, \text { Study 1) }\end{array}$ & $\begin{array}{l}\text { (1) Watch experimenter's } \\
\text { possessions; a theft at- } \\
\text { tempt is later thwarted } \\
\text { by the subject } \\
\text { (2) Same as (1); the second } \\
\text { request is made by a } \\
\text { different experimenter }\end{array}$ & $\begin{array}{l}\text { Give money to experimenter to } \\
\text { permit the purchase of food }\end{array}$ & $\begin{array}{l}\text { (1) } 20^{e} \\
\text { (2) } 40 \\
\text { (C) } 35\end{array}$ & $\begin{array}{l}\text { No FITD } \\
\text { No FITD }\end{array}$ \\
\hline
\end{tabular}


Table 1 (continued)

\begin{tabular}{|c|c|}
\hline Study & First request \\
\hline $\begin{array}{l}\text { Harris \& Samerotte } \\
\quad(1976, \text { Study 2) }\end{array}$ & $\begin{array}{l}\text { (1) Watch experimenter's } \\
\text { possessions; a theft at- } \\
\text { tempt is later thwarted } \\
\text { by the subjects } \\
\text { (2) Same as (1); the second } \\
\text { request is made by a dif- } \\
\text { ferent experimenter } \\
\text { (3) Watch experimenter's } \\
\text { possessions; no theft } \\
\text { attempt is made } \\
\text { (4) Same as (3); the } \\
\text { second request is made } \\
\text { by a different ex- } \\
\text { perimenter }\end{array}$ \\
\hline Lowman (1973) & $\begin{array}{l}\text { (1) Answer four questions } \\
\text { on recycling and con- } \\
\text { tainer use }\end{array}$ \\
\hline $\begin{array}{l}\text { Miller \& Suls } \\
\quad(1977)\end{array}$ & $\begin{array}{l}\text { (1) Give directions that } \\
\text { are difficult to explain } \\
\text { (2) Give directions that } \\
\text { are simple to explain }\end{array}$ \\
\hline $\begin{array}{l}\text { Pliner, Hart, } \\
\text { Kohl, \& Saari } \\
\text { (1974) }\end{array}$ & $\begin{array}{l}\text { (1) Wear pin to advertise } \\
\text { a fund drive } \\
\text { (2) Wear pin and persuade } \\
\text { member of family to do } \\
\text { so }\end{array}$ \\
\hline
\end{tabular}
$\underset{\text { (1977) }}{\text { Reingen \& Kernan }}$

Seligman, Bush, \& Kirsch (1976)

Seligman, Miller, Goldberg, Gelberd, Clark, \& Bush (1976)

\section{Snyder \& Cun- ningham (1975)}

(1) Agree to participate in a 5-question survey on household products

(1) Answer 5 questions on the energy crisis and inflation

(2) Answer 20 questions

(3) Answer 30 questions

(4) Answer 45 questions

(1) Listen to a 2-minute, pro-McGovern speech; agree to display a small campaign sign

(2) Agree to display a small campaign sign only

(3) Listen to a 2-minute speech on fire prevention, agree to display a small fire prevention sign

(4) Agree to display a small fire prevention sign only

(1) Agree to answer 8 questions on household paper products or on traffic safety
Agree to participate in a glass and metal trash recycling program

Help a male experimenter pick up dropped groceries

(1) 85

(C) 68

(1) 14

(2) 29

(3) 50

(4) 21

(C) 29

Conclusion

No FITD

No FITD

No FITD

No FITD

(1) 12

(2) 64

No FITD

FITD

(C) 32

Contribute money to the fund

(1) 74

FIT D

(2) 81

(C) 46

FITD

Agree to participate in a $20-$

(1) 75 question survey on household $\quad$ (C) 58 products

Agree to answer 55 more questions for the same survey

(1) 38

No FITD

(2) 35

(3) 74

(4) 74

(C) 31

No FITD

FITD

FITD

Agree to display a McGovern poster in front window

(1) 38

FITD

(2) 23

No FITD

(3) 30

(4) 31

No FITD

(C) 16

No FITD

Agree to answer 30 questions for the other organization
(1) 52

(C) 33 
Table 1 (continued)

\begin{tabular}{|c|c|c|c|c|}
\hline Study & First request & Second request & Results ${ }^{a}$ & $\begin{array}{l}\text { Con- } \\
\text { clusion }\end{array}$ \\
\hline $\begin{array}{l}\text { Tipton \& Brown- } \\
\text { ing (1972) }\end{array}$ & $\begin{array}{l}\text { (1) Help an elderly woman } \\
\text { pick up dropped } \\
\text { groceries }\end{array}$ & $\begin{array}{l}\text { Help a young woman in a } \\
\text { wheelchair up over a curb }\end{array}$ & $\begin{array}{l}\text { (1) } 0^{f} \\
\text { (C) } 36\end{array}$ & No FITD \\
\hline Uranowitz (1975) & $\begin{array}{l}\text { (1) Watch experimenter's } \\
\text { shopping bags while he } \\
\text { retrieves a dollar bill } \\
\text { (2) Watch experimenter's } \\
\text { shopping bags while he } \\
\text { retrieves his wallet }\end{array}$ & $\begin{array}{l}\text { Notify a second experimenter } \\
\text { that she dropped her package }\end{array}$ & $\begin{array}{l}\text { (1) } 80 \\
\text { (2) } 45 \\
\text { (C) } 35\end{array}$ & $\begin{array}{l}\text { FITD } \\
\text { No FITD }\end{array}$ \\
\hline $\begin{array}{l}\text { Zuckerman, Laz- } \\
\text { zaro, \& Waldgeir } \\
\text { (in press) }\end{array}$ & $\begin{array}{l}\text { (1) Agree to participate } \\
\text { in a 5-minute survey on } \\
\text { traffic safety }\end{array}$ & $\begin{array}{l}\text { Agree to participate in a } 20 \text { - } \\
\text { minute survey on household } \\
\text { products }\end{array}$ & $\begin{array}{l}\text { (1) } 64 \\
\text { (C) } 45\end{array}$ & No FITD \\
\hline
\end{tabular}

Note. The first condition in a study is indicated by (1), the second condition by (2), and so on; results are described accordingly; $(C)=$ the no-initial-request control group; FITD $=$ the foot-in-the-door effect.

${ }^{a}$ Results are reported as the percentage of subjects complying with the second request. A chi-square test (corrected for continuity) was executed for comparisons between individual experimental groups and the control group. If $p<.10$, it is concluded that the foot-in-the-door effect was successfully replicated. If a chi-square could not be executed based on the information provided by the authors, the conclusions based on the authors' own statistical comparisons are reported.

b Data reported are for subjects run by the male experimenters. Percentage compliance for subjects run by the female experimenters is not reported, but no FITD effect was found. For Condition 2 (male experimenters), $p>.10$ by chi-square, according to Baron (1973).

- Data reported are for verbal compliance with the request. Actual compliance was as follows: (1) $10 \%$; (C) $20 \%$.

${ }^{d}$ Data are reported in terms of average summed difficulty level of volunteered activities; data on percentage compliance are not reported. In a previous experimental session, all subjects run in this study were given false physiological feedback, which led them to believe they might harbor racial prejudice.

- Data have been collapsed across the variable of type of food to be purchased by the experimenter.

' Only those who helped the elderly woman were included as subjects in the experimental condition. Despite the bias toward confirmation this procedure created, no foot-in-the-door effect was found.

a severe test. For example, most studies that ask the subjects to participate in a survey as the initial request also seek their participation in a second survey. As noted previously, Freedman and Fraser (1966, Study 2) actually manipulated the degree of similarity between the two requests in terms of the issue involved and the mode of action required of subjects, but they found those factors to have little impact on compliance with the second request. Seligman, Miller, Goldberg, Gelberd, Clark, and Bush (1976) also failed to find generally higher compliance when the two requests were similar.

\section{Self-Perception Explanation}

Freedman and Fraser (1966) were surprised to learn that the size of the foot-in-thedoor effect they obtained did not depend on the nature of the first request. As noted before, possible explanations for the effect centering around subjects' commitment to a particular experimenter, organization, issue, or mode of action were effectively ruled out. To account for their unexpected results, they offered the following explanation:

What may occur is a change in the person's feelings about getting involved or about taking action. Once he has agreed to a request, his attitude may change. He may become, in his own eyes, the kind of person who does this sort of thing, who agrees to requests made by strangers, who takes action on things he believes in, who cooperates with good causes. (Freedman \& Fraser, 1966, p. 201)

Thus, the self-perception mediation of the foot-in-the-door phenomenon involves a twostage process. First, people must observe their own behavior and the situational context in 
which it occurs and, from those data, make an inference about their own dispositions and attitudes. It has been argued that subjects comply with the initial request in the apparent absence of any external inducements and then decide on the basis of that evidence that they are the kind of people who cooperate with good causes or help out other people. ${ }^{1}$ Second, this changed self-perception is thought to increase the probability of their performance of similar kinds of action in the future. As presently articulated, self-perception theory does not adequately explain the processes that mediate this last step (cf. Bem, 1972).

The self-perception explanation of the footin-the-door phenomenon has led to the formulation of several testable hypotheses. The evidence for each of these is now considered.

\section{Size of the Initial Request}

A straightforward prediction derived from self-perception theory is that the larger the size of the first request to which people agree, the greater the probability of their compliance to the second larger request. In other words, the greater the costs of compliance with the initial request, the more likely it should be for people to find dispositional meaning in their behavior. To test this hypothesis, Seligman, Bush, and Kirsch (1976) first asked subjects to answer either $5,20,30$, or 45 short questions for a survey on reactions to the energy crisis and inflation. There were no differences among those four conditions with regard to compliance with the first request for help. Later, subjects were called back by a different experimenter representing the same survey group and were asked to answer 55 more questions. Unexpectedly, subjects in the 5- and 20-question groups were not more likely to answer the 55 questions than were control subjects contacted for the first time. However, the two larger initial requests were effective in inducing significantly higher rates of compliance with the second request.

Seligman, Bush, and Kirsch recognized the possibility that sufficiently large initial requests might discourage subsequent compliance, but evidence for that was not found in their study. It should be noted that subjects in all cases were told the survey would require only "a couple of minutes," thus making even the larger requests seem relatively small. A study by Miller and Suls (1977) suggests the possibility of a curvilinear relationship between size of the initial request and subsequent compliance. Subjects in their experiment were asked to give street directions to a first experimenter, the directions being either difficult or simple to explain. Compared with control group subjects, those who gave the simple directions were more likely to help a second experimenter pick up his dropped groceries a few moments later. Those who gave the difficult directions were less likely to help. Existence of a curvilinear relationship, of course, could not be explained by selfperception theory alone.

\section{Agreement to the Request Versus Actual Performance}

It could also be predicted from self-perception theory that compliance with the second request would be more likely if subjects actually performed what was asked of them in the initial request than if they agreed to comply but were never called upon to carry out their promise. The only study that directly addressed this issue is an experiment reported by Freedman and Fraser (1966, Study 1). Housewives in the so-called agree-only condition were asked to participate in a consumer survey about household products; those willing to help were told the survey would be conducted at a later time. Subjects in the performance condition actually participated in the survey. In a later call, the same experimenter asked subjects if they would permit a

\footnotetext{
1 Self-perception theory has not articulated well the exact nature of the self-perception changes that are said to occur. It is not clear, in the case of most foot-in-the-door studies, whether subjects classify their behavior as compliance or as helping. This uncertainty is due to the fact that most experimenters use compliance with a request for help as their dependent measure (see Table 1). Experiments that instead require subjects to initiate help giving (e.g., Miller \& Suls, 1977; Uranowitz, 1975) suggest that most subjects may view their assent to the first request as helpfulness.
} 
survey team to come into their homes to list the household products they used. Whereas $22 \%$ of the control group subjects agreed to that request, over half the subjects in the performance condition did so. In contrast, a mere $33 \%$ of the agree-only condition subjects complied with that request. A clear theoretical interpretation of these results is made difficult by the fact that subjects in the agree-only condition did not learn the exact size of the request to which they had agreed. Their compliance to the second request may have been lower only because they guessed the initial request to be quite large (cf. Miller \& Suls, 1977). Parenthetically, it must be noted that other experimenters have shown that actual performance of the initial request is not requisite in demonstrating the foot-inthe-door effect (e.g., Snyder \& Cunningham, 1975; Zuckerman et al., in press).

\section{Effect of Noncompliance With the Initial Request}

Self-perception theory led Snyder and Cunningham (1975) to predict that subjects induced not to comply with an initial request would be less likely to comply with a second request. In their experiment, one group of subjects was first asked to participate in a 50-question telephone survey, a request sufficiently large to guarantee almost universal noncompliance. Two days later, a differentsexed experimenter representing a second organization asked subjects to answer 30 questions. Consistent with their prediction, subjects initially approached with the large request were less compliant with the second request than were subjects in the control group. Similar results were reported by Cann et al. (1975) and Reingen and Kernan (1977). These studies support the idea that induction of initial noncompliance leads people to perceive themselves as the kind of people who do not comply with such requests. One might predict that the smaller the request that people refuse, the lower the probability of their compliance to a second request; this proposition remains to be tested.

An added complication arises when the timing of the second request is considered. In two studies, Cann et al. (1975) reported that noncompliance with a large initial request actually led to greater compliance when the second request was made immediately after the first, rather than after a delay period of several days. For example, one study showed that $90 \%$ of the subjects agreed to an immediate second request after having refused the experimenter's initial large request, compared with $50 \%$ in the control group. Only $29 \%$ compliance was obtained when that second request was made 7-10 days later.

These findings replicate an effect first demonstrated by Cialdini et al. (1975), which they dubbed the "door-in-the-face" technique. Quite simply, these authors claimed that if an experimenter first approaches subjects with an unreasonable request that is sure to be refused, but then immediately asks a smaller favor, subjects will view the experimenter's action as a concession. The subjects, in turn, will feel normative pressure to reciprocate that concession, and they will respond to that pressure with compliance with the second request. Replications of this effect abound (Cialdini \& Ascani, 1976; Miller, 1974; Miller, Seligman, Clark, \& Bush, 1976; Reingen, 1977).

In one experiment, Cialdini et al. (1975) demonstrated that the subjects' perception of the encounter as a kind of bargaining situation probably underlay the effect. In the rejection-moderation condition, both requests for help were made by the same experimenter. In the so-called two-requester condition, subjects' noncompliance with the first request was followed immediately by another request put to them by a second experimenter. This second experimenter was seemingly unrelated to the first, but subjects knew this person had overheard their conversation with the first experimenter. Whereas a control procedure produced a $31 \%$ compliance rate, $55 \%$ of the rejection-moderation condition subjects consented to the second request. But when that same second request was made by a different experimenter, only $10 \%$ of the subjects in the two-requester condition complied, a result consistent with those reported by Snyder and Cunningham (1975). The authors argued that subjects in the latter condition could 
not interpret the second request as a concession, simply because it was made by a different experimenter, ${ }^{2}$

Why do subjects in the door-in-the-face procedure who do not comply with the initial large request not come to see themselves as the kind of people who refuse such requests, as Snyder and Cunningham's (1975) results might lead us to expect? Even-Chen, Yinon, and Bizman (1978) argued that the initial requests used by Cialdini et al. (1975) and others were too large for subjects to draw dispositional inferences from their failure to comply. Implicit in their argument is the suggestion that subjects must believe the request is one to which someone (though not they) might consent in order for a self-perception change to occur. In their study, when subjects refused a large, but not reasonable, first request, they were less likely to agree to a second smaller request. Only those who refused an extremely large request showed a subsequent door-in-the-face effect. These results are suggestive, but Even-Chen et al.'s argument cannot account for the results obtained by Cialdini et al. In the earlier experiment, whether a door-in-the-face effect or a result consistent with self-perception theory was found depended solely on who made the second request.

In general, research on the effect of initial noncompliance has been supportive of the self-perception hypothesis. Only under a special set of circumstances, that is, when the first request is extremely large and the second request can be viewed as a concession on the part of the experimenter, does an initial refusal not lead to subsequent refusals.

\section{Effect of Consensus Information}

The self-perception analysis of the foot-inthe-door effect leads to the prediction that if subjects were informed they were not unique in their compliance with the initial request, they would be induced to see their behavior as determined by situational pressures and not to view it as having any implications for their own traits or attitudes (cf. Cook, Pallak, \& Sogin, 1976; Cooper, Jones, \& Tuller, 1972). In one recent experiment designed to test this prediction (DeJong, Note 2), shoppers were approached individually by a physically able male experimenter and shown a card on which was written the resolution of a petition formulated by a group called the Upper Valley Foundation to Help the Handicapped. After reading the resolution, $87 \%$ of the subjects agreed to sign the petition. At that point, some subjects were shown a petition with many signatures and one blank space at the bottom (consensus condition). As they signed, the experimenter said, "As you can see, almost everyone we've asked has signed our petition." The other subjects were shown a completely blank petition, and as they signed, the experimenter noted that they were the only ones so far to do so (nonconsensus condition). When the subjects walked on, a second male experimenter dropped a quarter as he walked some 15 to 20 feet ahead of them. Thirty-two percent of the subjects in the no-initial-request control group notified the second experimenter of his loss, whereas $64 \%$ of those told that many people had signed the petition did so. Unexpectedly, only $28 \%$ of those told they had been unique in their agreement to sign helped the second experimenter.

Consensus information is more psychologically complex than attribution theorists have admitted (cf. McArthur, 1973). In addition to pointing to the power of situational constraints on behavior (Kelley, 1967), consensus information can help define the behavioral norms that are operative in a specific context. Subjects in the consensus condition may have helped the second experimenter more often because they were reminded that helping others was appropriate behavior. In addition,

\footnotetext{
2 Pendleton and Batson (1979) offered a self-presentation explanation of the door-in-the-face technique, suggesting that subjects are motivated to comply with the second request to avoid being perceived as unhelpful. Although the results for Cialdini et al.'s (1975) two-requester control group seem to counter this alternative, Pendleton and Batson argued that the phrasing of the second experimenter's request ("But maybe you could help $m e$ ") may have induced reactance, thus producing a low rate of compliance in that condition. Further research is needed to resolve this controversy.
} 
consensus information can reaffirm the reasonableness of one's own behavior. Subjects in the nonconsensus condition may have been shocked to learn of their unique status and may literally have been "lost in thought" when the second experimenter dropped his quarter. To date, no foot-in-the-door study involving the introduction of consensus information has yielded results consistent with self-perception theory.

\section{Presence of External Justification}

Theoretical analyses of attributional processes (Kelley, 1967) propose that people assign dispositional meaning to behavior after a careful assessment of the possible explanatory power of controlling influences in the environment. Thus, a self-perception account of the foot-in-the-door phenomenon stresses that the amount of external pressure used to induce compliance with the initial request is paramount. If those external pressures provide people with an adequate explanation of their behavior, they will not be led to infer anything about their own traits or attitudes. Under those circumstances, an increased probability of compliance with subsequent requests for help would not be expected. Indeed, Lepper (1973) even suggested the possibility of an "overjustification" effect; that is, if people comply with an initial request under conditions of strong external justification, they may come to infer that they are extrinsically motivated and that they are the kind of people who agree to such requests only when external pressures are present. As a result of this kind of changed self-perception, people may actually come to be less likely to comply with future requests when those kinds of pressures are absent.

The impact of external justifications for the initial act of compliance on subsequent helping was demonstrated by Uranowitz (1975). Female shoppers were asked by an experimenter to watch his grocery bags while he ran back to retrieve a lost article. In the highjustification condition, he claimed he had lost a wallet containing a lot of money; in the low-justification condition he said that he had dropped only a dollar bill. The assumption, of course, was that subjects in the high-justification condition would believe that circumstances demanded their compliance and that anyone faced with such a request would agree to it. When the first experimenter returned with the lost article, the subject proceeded on her way. A female experimenter later dropped a package in the subject's path, and the subject's response was noted. The results were striking. Eighty percent of the subjects in the low-justification condition helped the second experimenter, whereas only $45 \%$ of the highjustification and $35 \%$ of the control subjects did so.

Zuckerman et al. (in press) investigated this same problem using an experimental procedure modeled after that used by Snyder and Cunningham (1975). Housewives were first asked to take part in a 5-minute telephone survey; some were promised a monetary payment in exchange for their cooperation, and others were not. If a subject agreed to participate, she was told that the interview would be conducted at a later time. Subjects promised the monetary payment were told they would receive a check after the interview. Two or three days later, the subjects were called by a second experimenter representing a different service organization and were asked to consent to a 20-minute interview. Forty-five percent of the control group subjects agreed to that request, whereas $64 \%$ of the subjects promised no money consented to the interview. In contrast, only $33 \%$ of those promised a monetary payment in return for their initial compliance agreed to the second request. Similar results were reported by Reingen and Kernan (1977).

DeJong and Funder (1977), however, found the monetary payment to have the opposite effect. The day after their participation in a 15-question survey, subjects in the payment condition received the $\$ 2$ that had been promised them in exchange for their help. Subjects were later asked to take part in a 50-question survey being conducted by a second organization. Fifty-six percent of control subjects never before contacted agreed to the second request, whereas $78 \%$ of the subjects in the payment condition did so. These findings were unexpected. It was thought that the 
actual receipt of money by subjects in the payment condition would increase the salience of the external justification for their compliance with the first request. A follow-up study showed that this finding was not due to subjects' expectation that they would be paid for helping with the second survey. When the second caller informed subjects they could not be paid for their help, the pattern of results was virtually unchanged. One possible explanation for this unexpected set of results is that a letter that accompanied the payment may have labeled subjects as "doers" (cf. Kraut, 1973). That certification may have had greater implications for subjects' selfperceptions than did the small monetary payment.

Finally, in a study conducted by DeJong and Musilli (Note 3), subjects were approached at home with a small initial request made by a female experimenter who appeared to be either handicapped or physically normal. It was hypothesized that subjects approached by the disabled experimenter would feel psychological pressure to comply with her request and would, in turn, attribute their compliance to the fact of her disability. The experimenter asked half the subjects to answer questions for a survey on special parking facilities for disabled drivers for a group called Friends of the Handicapped. The others were told that the experimenter represented Friends of the Environment and that the questions concerned special parking for compact cars. Two days later, subjects were called on the telephone by a second experimenter and were asked to participate in a 30 -minute survey on traffic safety for a different organization. The hypothesis was partially supported. Fifty-six percent of the subjects approached by the handicapped experimenter for Friends of the Handicapped complied with the second request, whereas $40 \%$ of control subjects did so. However, only $41 \%$ of subjects approached by the handicapped experimenter for Friends of the Environment complied with the second request.

In sum, evidence is generally consistent with the proposition that high external justification for initial acts of compliance can dampen the probability of subsequent compliance.
Only one study found no such effect at all (DeJong \& Funder, 1977), and there is a plausible explanation for that failure. Little evidence for an overjustification effect exists; only Reingen and Kernan (1977) and Zuckerman et al. (in press) reported results for a high-justification condition to be actually below those for a control group, and these differences were small. One possible reason for not finding overjustification effects is that subjects in these studies were not preselected for their high level of initial intrinsic or altruistic motivation.

There may be circumstances under which high external justification for initial compliance actually leads to higher levels of subsequent compliance. Such an outcome might be anticipated if people believe that behavior that is truly intrinsically motivated is more highly regarded than that which is thought to arise in response to external pressure (cf. Nemeth, 1970). Thus, when subjects' selfesteem (or their good name) is threatened by the perception that they have complied in response to the dictates of external contingencies, they may be motivated to be more helpful in the future when such pressures are absent. A report by Upton (1973) is consistent with this notion. He found that previous blood donors classified as intrinsically motivated did not respond well to an appeal for donations that offered money in exchange for a pint of blood. When no such bribe was offered, the percentage of such subjects willing to donate was almost 30 percentage points higher. It is conceivable that subjects offered the bribe wished to avoid the perception that they were motivated to help others only as a means of garnering rewards for themselves.

\section{Effect of Social Labels}

Sociological theories of deviance stress that society encourages those whom it labels as deviant to learn and accept a deviant role identity. Once such people come to share this definition of themselves, the changed selfimage is believed to sustain their deviant behavior (see Schur, 1971). Although these theories focus almost exclusively on labels of deviance and generally ignore positively val- 
enced labels, their basic propositions can still easily be translated into the language of selfperception theory. Though actual behavior (and the context in which it occurs) may provide the clearest evidence about one's traits or attitudes, self-perception theory recognizes that a self-definition or label provided by others may serve as an important source of information about one's dispositions (cf. Miller, Brickman, \& Bolen, 1975) or at least may signal to people that their behavior and its implications for their self-image should be reflected on, thereby energizing a self-perception analysis.

This proposition was put to the test by Kraut (1973). First, a male experimenter went to subjects' homes and solicited contributions for the Heart Association. If subjects made a donation, they were randomly assigned to be in a labeled or a nonlabeled condition. Subjects receiving the charitable label were simply told, "You are a generous person. I wish more of the people I met were as charitable as you." Subjects who did not contribute were also assigned to a labeled or a nonlabeled condition. Subjects receiving the label were frankly told that they were "uncharitable." One or two weeks later, a second experimenter contacted the subjects and asked for a donation to a fund-raising drive for multiple sclerosis. (Unfortunately, a control group consisting of subjects receiving only the second solicitation was not run.) As Kraut predicted, $62 \%$ of those given the positive label donated the second time, whereas only $47 \%$ of the nonlabeled subjects did so. Kraut recognized that this effect could be explained in terms of a social reinforcement model if the charitable label constituted a reward for the subjects. He also found that those who did not donate the first time gave somewhat less when they had been branded as uncharitable by the first experimenter, but this difference was not significant.

The impact of labels on self-perception and subsequent behavior was also examined in a study conducted by Paulhus, Shaffer, and Downing (1977). Prior to their actual donations, blood donors were asked to read communications that were designed to label their motives for giving blood. Half the subjects read a communication that emphasized altruistic motives, and as a cross-dimension, half the subjects were told about the personal benefits they would receive (e.g., free blood in case of emergency). After donating, subjects filled out a questionnaire that included an item on their plans for giving again within the next year. The results showed a main effect for salience of altruistic motives, such that subjects led to feel they had acted altruistically reported a greater likelihood of $\mathrm{fu}$ ture donation.

McArthur, Kiesler, and Cook (1969) labeled some subjects as doers (people who know what needs to be done and then take the appropriate action) on the basis of bogus test results. This positive label increased the proportion of subjects willing to help distribute antipollution leaflets only when subjects had been told that their doer personality qualified them to be paid for their participation in a second experiment. Apparently, subjects' belief that being a doer was a saleable quality strengthened the impact of the label, either because it made the feedback more convincing or simply because the subjects thought about it more.

In contrast, Steele (1975) expected labels to have effects different from those predicted by self-perception theory. $\mathrm{He}$ argued that a negative label (name-calling) that impugned subjects' character would motivate them to take action that would restore their selfesteem, thus increasing the probability that they would comply with a later request for help. Because positive labels would not do this, Steele expected them to have little impact on help giving. In this study, an experimenter claiming to be a pollster contacted subjects by telephone. In the relevant-negative-name condition, subjects were lambasted for being "apathetic about the welfare of others," whereas subjects in the irrelevantnegative-name condition were criticized for their lack of concern for driving safety. Recipients of the relevant-positive-name message were praised for their desire to help their fellow man. (No irrelevant-positive-name condition was run.) Two days later, subjects were called by a second experimenter representing a food cooperative in a lower income 
neighborhood. To help the cooperative achieve its goal of "aiding the less fortunate," subjects were asked to compile a detailed list of the quantities and brands of foods and household items used in their homes. Compared with a control group never before contacted, subjects receiving the positive label were more likely to help, though not significantly so (cf. Kraut, 1973). On the other hand, virtually all subjects in both negativename conditions promised to help out, and most actually did so. This effect was replicated in a second study.

The name-calling procedure employed by Steele (1975) differs from the labeling procedure used by other researchers in one important way. The labels used by others were based either on recent behavioral evidence (Kraut, 1973) or on the results of phony psychological tests (McArthur et al., 1969). In contrast, no such evidence substantiated the claim made by Steele's experimenter. This suggests that whether the negative label induces a change in self-perception may depend on the degree to which subjects' future behavior can belie the label. If refutation of the label is still possible, it may not lead to a change in self-definition, but may lead to a vigorous effort to defend self-esteem or to assuage guilt.

This possibility was explored in a recent study by Gurwitz and Topol (1978). Students at a large suburban university were first contacted by telephone and accused of not taking advantage of the opportunities afforded by a nearby city. This accusation was directed at subjects as members of a group (students at the university) or as individuals. Before the accusation was made, half the subjects were asked how many times in the past few months they had gone into the city, the modal answer being zero. The other subjects were not led in this way to provide evidence in support of the accusation. Later that evening, a second experimenter had subjects fill out a questionnaire concerning their interest in a number of student-organized activities in the city.

When subjects had not been led to provide evidence in support of the accusation, the degree to which they later belied the label depended on whether the accusation had been made about them as individuals or as members of a group. When they were seen as part of a group, they indicated more interest in the activities, thus belying the label. In contrast, when the subjects had been led to provide such evidence prior to the accusation, they were more likely to disconfirm the label when it had been directed at them as individuals. Similar results were found in a laboratory study conducted by Gurwitz and Topol (1978) in which subjects were labeled as being low in self-confidence. Why subjects' responses to the label depended so greatly on whether it was applied to them individually or as members of a group is not clear.

In sum, although the effect of positive labels has been fairly consistent across several studies, the impact of negative labels on subsequent behavior presents a more complicated picture.

\section{Measurement of Altered Self-Perceptions}

Perhaps the most convincing evidence in support of the self-perception explanation of the foot-in-the-door effect would come from studies that actually measured the changes in self-perception that are thought to occur. Unfortunately, this kind of direct evidence is hard to come by. A long catalog of excuses for this failure can be offered, most of them pointing to possible inadequacies in design and measurement (see Bem, 1972; Lepper, 1973). But the major difficulty may be that the self-perception changes that follow a person's initial compliance with a small request have never been clearly specified and may be much more complicated than has been acknowlếdged.

First, it may be unreasonable to expect the subjects' general perception of themselves to be altered by the kinds of brief experiences involved in these foot-in-the-door studies. In fact, particular subjects may only come to infer something about their attitudes or motives for a fairly limited set of situations (e.g., telephone solicitations from strangers). This notion is consistent with recent statements of self-concept theory (Gergen, 1971; 
McGuire \& Padawer-Singer, 1976), which emphasize that a person may harbor a variety of self-definitions that differ in salience across various situation contexts.

Second, measurement of these supposed changes in self-perception is made difficult by the fact that individuals are likely to code their behavior along different dimensions or into different groupings (Bem \& Allen, 1974). Which behaviors constitute actions that are psychologically similar to the initial act of compliance is a function of each person's view of the world. To give one example, some persons might code their behavior as compliance or as participating in a survey, whereas others might code it as helping someone in need.

For these two reasons, investigators who have hoped to show a general change in subjects' self-definitions seem to have had little chance of success. Still, two experiments have successfully demonstrated that extrinsic incentives for help giving can lead helpers to describe themselves as less altruistically motivated. During the course of an experiment on "first impressions," Batson, Coke, Jasnoski, and Hanson (1978) asked male undergraduates to help an experimenter code data. Payment for this help was offered before subjects agreed to help (payment condition), after the subjects' agreement (payment after), or payment was not mentioned at all (no payment). The request for help was always made in the presence of a male confederate who never volunteered his services. A control group received no such request. Subjects were then asked to rate themselves and the confederate on several dimensions, including helpfulness and cooperativeness. As expected, subjects who agreed to aid the experimenter in exchange for money rated themselves as less altruistic than the confederate, whereas subjects in the other three conditions rated themselves as more altruistic.

In an experiment conducted by Smith, Gelfand, Hartmann, and Partlow (1979), secondand third-grade children played a marble drop game in which they could earn pennies toward the purchase of a prize. During the first part of the experiment, the children were given a number of opportunities, signaled by a light, to donate pennies to another child playing the game in a nearby room. The experimenter also created situations in which the children could not make a donation (but would think they should have done so) by having the signal light go off before they could respond. Whereas some subjects were merely praised each time they donated a penny, others were given a monetary reward for doing so, and the relationship between their help giving and the reward was spelled out to them. Other subjects were scolded by the experimenter each time they did not avail themselves of an opportunity to help; another group of children were fined each time they failed to donate, and the contingency between their behavior and the punishment was made explicit. Finally, a control group did not receive any type of reward or punishment from the experimenter. Intensive interviews conducted by a second experimenter with each subject showed that children who were rewarded or fined were more likely to attribute their help giving to external pressures than were children in the control group or than were those who received praise or a scolding.

\section{Alternative Explanations for the Foot-in-the-Door Effect}

Surprisingly few alternative explanations for the foot-in-the-door effect have been suggested. In part, this is because the self-perception analysis has proven to be a heuristic explanation, leading investigators to examine a wide variety of phenomena such as overjustification effects and the impact of social labels. Other explanations have not generated much research, but they do resurface periodically. Three of these are considered.

\section{Adaptation Level}

It has been argued that the small initial request to which people agree establishes a new baseline against which the subsequent larger request is compared (e.g., Schmidt, 1973). In other words, the prior request causes the magnitude of the second to be redefined, making it seem less extreme than it 
otherwise would. It is not clear that this explanation would lead one to predict a difference in subsequent compliance between those who refuse and those who agree to the initial request. The perceived relative size of the second request should not depend very much on whether people have complied with the first request. However, several experiments show foot-in-the-door effects to be stronger when those who refuse the first request are excluded from the data analysis (e.g., Snyder \& Cunningham, 1975; DeJong \& Musilli, Note 3 ). It should be noted that this explanation cannot easily account for the results of studies looking either at extrinsic justification for the initial act of compliance or at the impact of social labels.

To lay this explanation permanently to rest, two types of studies could be done. First, subjects could be asked to rate the relative size of various requests under differing experimental conditions. Second, the subsequent compliance of those who are merely informed of a request being made of others and those who actually comply with that request could be compared. An adaptation level explanation would predict higher compliance from both of those groups, compared with a control group never before contacted, but self-perception theory would not.

\section{Salience of Social Norms}

Harris (1972) suggested that being asked to perform an initial small request makes people more aware of the norm of social responsibility, a norm that prescribes that one should help those who are in need. Like the adaptation level explanation, this argument also leads to the prediction that those who are only informed about the first request will be more compliant with the second demand. It would also lead us to expect a high rate of compliance from those who refuse the initial request, in contrast with available evidence. The major problem with this explanation, however, is that it, too, cannot account for the studies on extrinsic constraints or labels, which are better handled by the self-perception analysis.

\section{Behavioral Consistency}

It has also been argued that foot-in-thedoor demonstrations show that people try to act consistently with the way they have behaved in the past. Does a person induced to agree to a first request agree to a second in order to sustain a consistent public image? If the effect were due to subjects' attempts at such impression management, then a larger foot-in-the-door effect should result when the second request is made by the same experimenter or involves the same issue or action. The importance of these kinds of variables has not been adequately tested, but the available evidence suggests that similarity between the requests on these dimensions is not terribly important (e.g., Freedman \& Fraser, 1966).

A second version of this argument was suggested by Brock (1969), who argued, in essence, that people desire to be psychologically consistent for the sake of a self-image, not a public one. People have behaved in a certain way in the past and continue to behave that way in the future simply because they value consistency. However, it is clear that to manage a self-image in the fashion Brock suggested, people must first code their behavior and understand its attributional meaning. They must decide, essentially, whether the behavior reflects the pressures of extrinsic constraints or reflects their own dispositions or attitudes. Of course, it may be that the selfrewarding consequences of being consistent with one's self-image are what mediate the relationship between changes in self-perception and subsequent behavior. Evidence on this point is lacking.

\section{Conclusions}

1. It is concluded that the foot-in-the-door effect can be reliably obtained. Although the number of studies that have failed to demonstrate it unequivocally is surprising, it must be reemphasized that almost all of the studies reviewed showed experimental results in the predicted direction. Furthermore, a number of plausible explanations for failures to replicate can be offered. 
2. In addition to the self-perception explanation first offered by Freedman and Fraser (1966), three alternative explanations for the effect have been suggested. It is concluded that these explanations are inadequate accounts of the foot-in-the-door literature.

3. A number of theoretical derivations from the self-perception explanation of the foot-inthe-door effect have been outlined, and the evidence for most is found to be generally supportive. However, investigators have not clearly specified the exact nature of the selfperception changes that are said to mediate the foot-in-the-door effect. Self-perception theory must concern itself with how people classify or code their own behavior and how they are led to form a broad or highly specific inference about their attitudes, traits, or dispositions. Echoing Bem's (1972) admission, it must also be underscored that self-perception theory does not fully explain the link between self-attribution and subsequent behavior. Further work is needed to explore these gaps in the self-perception analysis of the foot-in-the-door effect.

\section{Reference Notes}

1. Crano, W. D., \& Sivacek, J. Social reinforcement, self-perception and the foot-in-the-door phenomenon. Unpublished manuscript, 1978. (Available from W. D. Crano, Department of Psychology, Olds Hall, Michigan State University, East Lansing, Michigan 48824.)

2. DeJong, W. Consensus information and the footin-the-door effect. Unpublished manuscript, 1978. (Available from W. DeJong, Department of Psychology, Brandeis University, Waltham, Massachusetts 02154.)

3. DeJong, W., \& Musilli, L. Handicapped versus non-handicapped requesters: The effect of pressure to comply with an initial request on the foot-inthe-door phenomenon. Paper presented at the meeting of the Eastern Psychological Association, Washington, D.C., March 1978.

\section{References}

Arbuthnot, J., et al. The induction of sustained recycling behavior through the foot-in-the-door technique. Journal of Environmental Systems, 1976-1977, 6, 353-366.

Baer, R., Goldman, M., \& Juhnke, R. Factors affecting prosocial behavior. Journal of Social Psychology, 1977, 103, 209-216.
Baron, R. A. Foot-in-the-door phenomenon: Mediating effects of size of first request and sex of requester. Bulletin of Psychonomic Science, 1973, 2, 113-114.

Batson, C. D., Coke, J. S., Jasnoski, M. L., \& Hanson, M. Buying kindness: Effect of an extrinsic incentive for helping on perceived altruism. Personality and Social Psychology Bulletin, 1978, 4, 86-91.

Beaman, A. L., Svanum, S., Manlove, S., \& Hampton, C. An attribution theory explanation of the foot-in-the-door effects. Personality and Social Psychology Bulletin, 1974, 1, 122-123.

Bem, D. J. Self-perception theory. In L. Berkowitz (Ed.), Advances in experimental social psychology (Vol. 6), New York: Academic Press, 1972.

Bem, D. J., \& Allen, A. On predicting some of the people some of the time: The search for crosssituational consistencies in behavior. Psychological Review, 1974, 81, 506-520.

Brock, T. C. On interpreting effects of transgression upon compliance. Psychological Bulletin, 1969, 72, 138-145.

Cann, A. A. The effects of performing a small consonant behavior on subsequent attitudes and behavior (Doctoral dissertation, Indiana University, 1975). Dissertation Abstracts International, 1976, 36, 5859B. (University Microfilms No. 76-11,359)

Cann, A., Sherman, S. J., \& Elkes, R. Effects of initial request size and timing of a second request on compliance: The foot in the door and the door in the face. Journal of Personality and Social Psychology, 1975, 32, 774-782.

Cialdini, R. B., \& Ascani, K. Test of a concession procedure for inducing verbal, behavioral, and further compliance with a request to give blood. Journal of Applied Psychology, 1976, 61, 295-300.

Cialdini, R. B., Cacioppo, J. T., Basset, R., \& Miller, J. A. The low-ball procedure for producing compliance: Commitment then cost. Journal of Personality and Social Psychology, 1978, 36, 463-476.

Cialdini, R. B., et al. A reciprocal concessions procedure for inducing compliance: The door-in-theface technique. Journal of Personality and Social Psychology, 1975, 31, 206-215.

Cook, D. A., Pallak, M. S., \& Sogin, S. R. The effect of consensus on attitude change and attribution of causality. Personality and Social Psychology Bulletin, 1976, 2, 248-251.

Cooper, J., Jones, E. E., \& Tuller, S. M. Attribution, dissonance, and the illusion of uniqueness. Journal of Experimental Social Psychology, 1972, 8, 45-47.

DeJong, W., \& Funder, D. Effect of payment for initial compliance: Unanswered questions about the foot-in-the-door phenomenon. Personality and Social Psychology Bulletin, 1977, 3, 662-665.

Dutton, D. G., \& Lennox, V. L. Effect of prior "token" compliance on subsequent interracial behavior. Journal of Personality and Social Psychology, 1974, 29, 65-71.

Even-Chen, M., Yinon, Y., \& Bizman, A. The door in the face technique: Effects of the size of the 
initial request, European Journal of Social Psychology, 1978, 8, 135-140.

Fish, B., \& Kaplan, K. J. Does a "foot-in-the-door" get you in or out? Psychological Reports, 1974, 34, $35-42$.

Freedman, J. L., \& Fraser, S. C. Compliance without pressure: The foot-in-the-door technique. Journal of Personality and Social Psychology, 1966, 4, 195202.

Gergen, K. J. The concept of self. New York: Holt, Rinehart \& Winston, 1971.

Gurwitz, S. B., \& Topol, B. Determinants of confirming and disconfirming responses to negative social labels. Journal of Experimental Social Psychology, 1978, 14, 31-42.

Harris, M. B. The effects of performing one altruistic act on the likelihood of performing another. Journal of Social Psychology, 1972, 88, 65-73.

Harris, M. B., Liguori, R., \& Joniak, A. Aggression, altruism, and models. Journal of Social Psychology, $1973,91,343-344$.

Harris, M. B., Liguori, R. A., \& Stack, C. Favors, bribes, and altruism. Journal of Social Psychology, 1973, 89, 47-54.

Harris, M. B., \& Samerotte, G. The effects of aggressive and altruistic modeling on subsequent behavior, Journal of Social Psychology, 1975, 95, 173-182.

Harris, M. B., \& Samerotte, G. The effects of actual and attempted theft, need, and a previous favor on altruism. Journal of Social Psychology, 1976, 99, 193-202.

Kelley, H. H. Attribution theory in social psychology. In D. Levine (Ed.), Nebraska Symposium on Motivation (Vol. 15), Lincoln: University of Nebraska Press, 1967.

Kraut, R. E. Effects of social labeling on giving to charity. Journal of Experimental Social Psychology, $1973,9,551-562$.

Lepper, M. R. Dissonance, self-perception, and honesty in children. Journal of Personality and Social Psychology, 1973, 24, 65-74.

Lowman, R. P. Recycling refuse: The effect of the foot-in-the-door technique on attitude and repetitive behavior (Doctoral dissertation, Claremont Graduate School, 1972). Dissertation Abstracts International, 1973, 33, 6114B. (University Microfilms No. 73-14,258)

McArthur, L. A. Perceiving the cause of one's own behavior: An unexpected reversal of Kelley's attribution theory. Psychological Reports, 1973, 32, 983-988.

McArthur, L. A., Kiesler, C. A., \& Cook, B. P. Acting on an attitude as a function of self-concept and inequity. Journal of Personality and Social Psychology, 1969, 12, 295-302.

McGuire, W. J., \& Padawer-Singer, A. Trait salience in the spontaneous self-concept. Journal of Personality and Social Psychology, 1976, 33, 743-754.

Miller, R. L. Facilitating compliance by manipulating the nature of the comparison: Relative cost vs. reciprocal concession. Personality and Social Psychology Bulletin, 1974, 1, 160-162.

Miller, R. L., Brickman, P., \& Bolen, D. Attribution versus persuasion as a means for modifying behavior. Journal of Personality and Social Psy. chology, 1975, 31, 430-441.

Miller, R. L., Seligman, C., Clark, N. T., \& Bush, M. Perceptual contrast versus reciprocal concession as mediators of induced compliance. Canadian Journal of Behavioural Science, 1976, 8, 401-409.

Miller, R. L., \& Suls, J. Helping, self-attribution, and size of an initial request. Journal of Social Psychology, 1977, 103, 203-208.

Nemeth, C. Effects of free versus constrained behavior on attraction between people. Journal of Personality and Social Psychology, 1970, 15, 302311.

Paulhus, D. L., Shaffer, D. R., \& Downing, L. L. Effects of making blood donor motives salient upon donor retention: A field experiment. Personality and Social Psychology Bulletin, 1977, 3, 99-102.

Pendleton, M. G., \& Batson, C. D. Self-presentation and the door-in-the-face technique for inducing compliance. Personality and Social Psychology Bulletin, 1979, 5, 77-81.

Pliner, P., Hart, H., Kohl, J., \& Saari, D. Compliance without pressure: Some further data on the foot-in-the-door technique. Journal of Experimental Social Psychology, 1974, 10, 17-22.

Reingen, P. H. Inducing compliance via door-in-theface and legitimization of paltry contributions. Psychological Reports, 1977, 41, 924.

Reingen, P. H., \& Kernan, J. B. Compliance with an interview request: A foot-in-the-door, self-perception interpretation. Journal of Marketing Research, $1977,14,365-369$.

Schmidt, L. G. The foot-in-the-door effect: $A n$ inquiry. Unpublished doctoral dissertation, University of South Carolina, 1973.

Schur, E. M. Labeling deviant behavior: Its sociological implications. New York: Harper \& Row, 1971.

Seligman, C., Bush, M., \& Kirsch, K. Relationship between compliance in the foot-in-the-door paradigm and size of first request. Journal of Personality and Social Psychology, 1976, 33, 517-520.

Seligman, C., Miller, R., Goldberg, G., Gelberd, L., Clark, N., \& Bush, M. Compliance in the foot-inthe-door technique as a function of issue similarity and persuasion. Social Behavior and Personality, 1976, 4, 267-271.

Smith, C. L., Gelfand, D. M., Hartmann, D. P., \& Partlow, M. E. Y. Children's causal attributions regarding help-giving. Child Development, 1979, 50, 203-210.

Snyder, M., \& Cunningham, M. R. To comply or not comply: Testing the self-perception explanation of the "foot-in-the-door" phenomenon. Journal of Personality and Social Psychology, 1975, 31, 64-67. Steele, C. M. Name-calling and compliance. Journal 
of Personality and Social Psychology, 1975, 31, 361-369.

Tipton, R. M., \& Browning, S. Altruism: Reward or punishment. Journal of Psychology, 1972, 80, 319322.

Upton, W. E. Altruism, attribution, and intrinsic motivation in the recruitment of blood donors (Doctoral dissertation, Cornell University, 1973). Dissertation Abstracts International, 1973, 34, 6260B. (University Microfilms No. 74-12,652)
Uranowitz, S. Helping and self-attributions: A field experiment. Journal of Personality and Social Psychology, 1975, 31, 852-854.

Zuckerman, M., Lazzaro, M. M., \& Waldgeir, D. Undermining effects of the foot-in-the-door technique with extrinsic reward. Journal of Applied Social Psychology, in press.

Received December 1, 1978

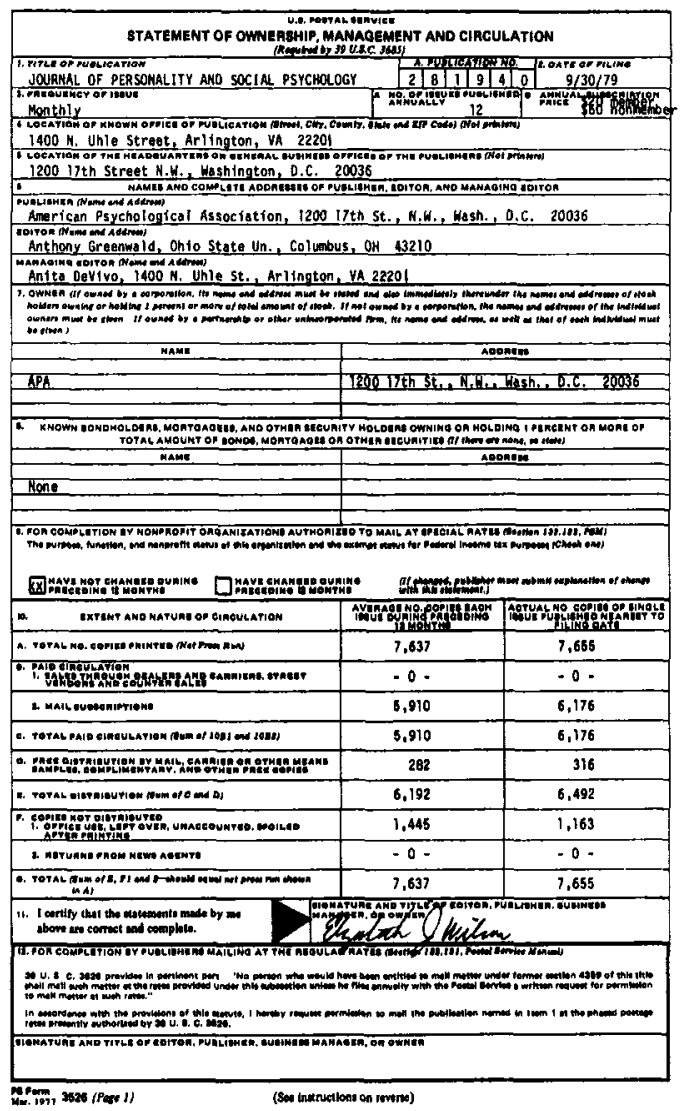

